\title{
LICHEN SPECIES DIVERSITY Yellowstone National Park GLORIA site
}

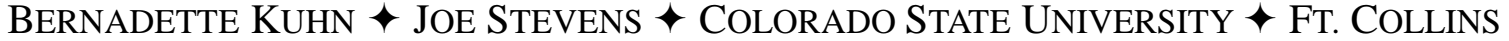

\section{$\uparrow \quad$ ABSTRACT}

Alpine ecosystems are important monitoring targets for examining climate-induced changes of vegetation cover, species composition, and species migration. In 2011, we installed alpine monitoring sites in Yellowstone National Park for the Rocky Mountain Inventory and Monitoring Network. The site was established using the protocol developed by the Global Observation Research Initiative in Alpine Environments [GLORIA] (Grabher et al. 2000). Here, we present a summary of the lichen species diversity documented within these monitoring plots, as well as the summary of field work completed for the GLORIA project in 2011. We report on the results of 40 numbered collections of lichens collected at four alpine sites in the Absaroka Range, Yellowstone National Park. A total of 21 unique taxa were documented. Of these, 6 are new to the documented

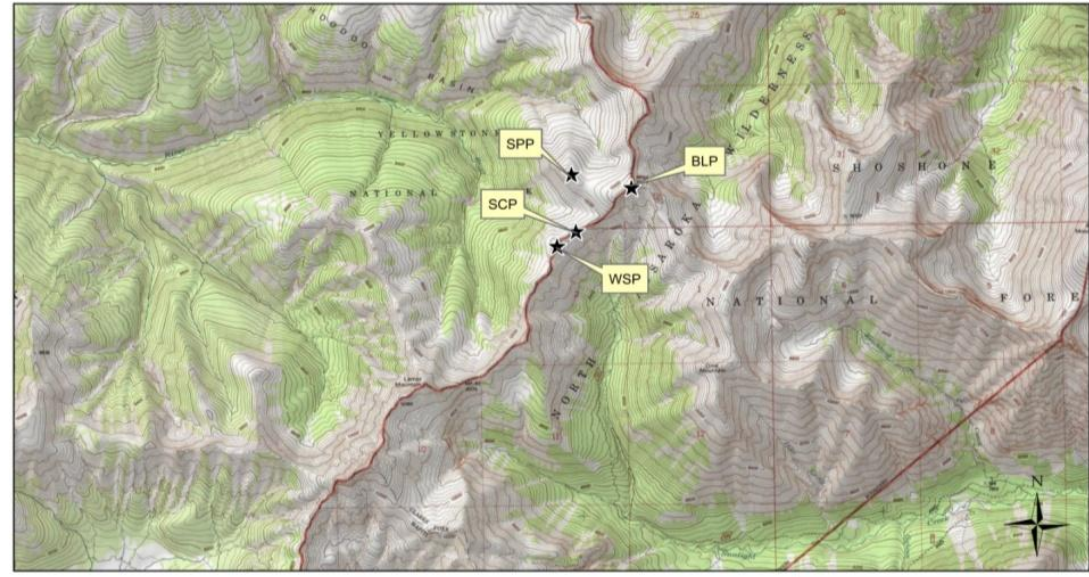

Legend

$\star$ GLORIA Peaks

0.250 .5

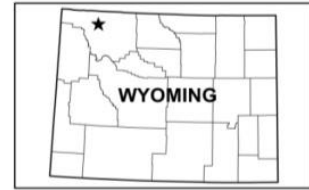

lichen flora of Yellowstone (Eversman 1998, Eversman et al. 2002).

\section{$\uparrow \quad$ INTRODUCTION}

Unlike vascular flora, comprehensive works documenting lichen and moss diversity in the Northern Rockies are fairly recent (Eversman 1990, Eversman 1998, Eversman et al. 2002, Flora of North America editors 2007, McCune and Goward 1995). Nascent efforts to document lichen diversity within Yellowstone National Park [YELL] have largely been limited to trail corridors and roadsides (Eversman 1990, Eversman 1998, Eversman et al. 2002). Therefore, alpine lichen diversity is poorly documented (Figure 1). Existing checklists for YELL report 8 out of 54 collection sites in the alpine (Eversman 1990, Eversman et al. 2002). Alpine
Figure 3. Locations of Four Sentinel GLORIA Peak in Yellowstone National Park. 
Table 1. Name, location, elevation, and vegetation zone of the four alpine sentinel sites within Yellowstone National Park.

\begin{tabular}{|l|l|l|l|l|l|}
\hline $\begin{array}{l}\text { GLORIA } \\
\text { Summit code }\end{array}$ & $\begin{array}{l}\text { Summit } \\
\text { name }\end{array}$ & $\begin{array}{l}\text { Latitude (decimal } \\
\text { degrees) }\end{array}$ & $\begin{array}{l}\text { Longitude } \\
\text { (decimal } \\
\text { degrees) }\end{array}$ & Elevation (m) & Vegetation zone \\
\hline BLP & Unnamed & 44.700184 & -109.826731 & 3,195 & lower alpine \\
\hline SCP & Unnamed & 44.695765 & -109.834566 & 3,122 & lower alpine \\
\hline SPP & Unnamed & 44.701613 & -109.835067 & 3,169 & lower alpine \\
\hline WSP & Unnamed & 44.694275 & -109.837219 & 3,124 & lower alpine \\
\hline
\end{tabular}

mosses are traditionally under-collected by previous bryologists (personal communication Harpel 2011, Spence 1985, Eckel 2007). However, a comprehensive checklist of the moss flora of the Greater Yellowstone Area is in progress (personal communication Harpel 2011).

In this study, we installed and sampled a long-term alpine monitoring site in YELL to examine the composition and structure of vascular and nonvascular plant species. Most vegetation monitoring conducted in National Parks does not include sampling non-vascular species. Thus, the project provided a unique opportunity to further the existing knowledge of alpine lichen and moss species diversity within YELL.

The long-term monitoring site was established by Colorado Natural Heritage Program [CNHP] biologists through a joint project with the National Park Service's Rocky Mountain Inventory and Monitoring Network [ROMN]. The primary objective of this project is to examine climateinduced changes of alpine vegetation cover, species composition, and species migration. The site was established using protocol developed by the Global Observation Research Initiative in Alpine Environments [GLORIA]. Here, we present a summary of the lichen species diversity documented within these monitoring plots, as well as the summary of field work completed for the GLORIA project in 2011. Since 2011 was the initial sampling year of the GLORIA site, this report does not focus on analysis of plot data, nor does it examine trends. Full sampling events are scheduled every 5 years for this site. We expect to produce reports and publications with in-depth analysis and interpretation following the second full sample event.

\section{METHODS}

We implemented an alpine monitoring protocol from the Global Observation Research Initiative in Alpine Environments (GLORIA), an international monitoring network established in 2001 to assess and predict biodiversity and temperature changes in alpine communities in response to drivers such as climate (Pauli et al. 2010). Supplemental protocol from ROMN was added regarding human disturbance and soils. The goals of the GLORIA program are to provide a global baseline for vegetation monitoring in alpine environments and to assess the risks of biodiversity loss and ecosystem instability from climate change. The methodology is extended by cooperators, such as the ROMN and CNHP, to create a long-term monitoring network at the global scale. The ROMN Alpine Vegetation Composition, Structure, and Soils protocol follows established GLORIA protocols but adds components for soil condition, treeline movement, and human disturbances (Ashton et al. 2010).

\section{Sample design}

We followed the GLORIA sampling design (Pauli et al. 2010) which calls for the establishment of four sentinel sites on alpine peaks representing an elevation gradient within a target region (e.g. the Absaroka Range in eastern Yellowstone National Park, WY). One GLORIA region includes four sites. The sites are established on the top of the peaks (summits) and the summits vary from just above treeline to the highest life zones of vegetation. Within one region, all four summits share qualitatively similar geology, climate, disturbance, and land-use history leaving vegetation differences among the summits to be driven primarily by elevation.

In 2011, we established monitoring sites at four summits within Yellowstone National Park (USYEL; Figure 1; Table 1). We examined topographic maps and photographs, discussed options with park managers, took a reconnaissance flight over the area, and hiked to potential sites to select the best summits. The summits we chose are within close proximity of one another and are located in the Upper Lamar River area, on a ridgeline that runs north of Lamar Mountain. The four peaks have similar geology, similar land-use history and disturbance levels, and a similar climate. We permanently marked the sites to ensure accurate relocation, buried $\mathrm{HOBO}(\mathrm{C}$ Onset pendant temperature loggers (UA-001-64) on the north, east, south and west side of all peaks to acquire hourly temperature data for the winter of 2011-2012, and drafted preliminary species lists for the four sites. 
At each peak, we installed one marker (a rebar with a labeled aluminum cap) at the highest point on the summit, and identified and marked $9 \mathrm{~m}^{2}$ quadrat clusters in each cardinal direction at exactly 5 $\mathrm{m}$ in elevation below the summit (all four corners of the quadrat cluster are marked: one with capped rebar and 3 with nails; Figure 2).

\section{Plot layout}

Once the summits were selected, we established a long-term monitoring plot at each of the summit sites (Figure 2). For each peak, this entailed placing one marker (a rebar with a labeled aluminum cap) at the highest point on the summit, identifying and marking a $3 \times 3 \mathrm{~m}$ quadrat cluster (Figure 3 ) in each cardinal direction at exactly $5 \mathrm{~m}$ in elevation below the summit (all four corners of the quadrat cluster are marked: one with capped rebar and 3 with nails; Figure 2), and identifying 4 lower and 4 upper summit area sections that describe each aspect to a distance of $10 \mathrm{~m}$ below the summit (e.g., the upper north section was the north side from the summit to 5 $\mathrm{m}$ below the summit and the lower was from 5 to 10 $\mathrm{m}$ below the summit).

Vegetation, Soils, Temperature, and Disturbance Monitoring

The quadrat clusters each contain 9-1 $\mathrm{m}^{2}$ quadrats (Figure 2, 3) that are used to measure fine changes in vegetation cover and frequency. In addition, one temperature datalogger is buried at 10 $\mathrm{cm}$ depth in the center of each quadrat cluster to measure changes in soil temperature over time and variation in temperature associated with aspect. The $1 \mathrm{~m}^{2}$ quadrats are also used to record the presence and frequency of herbivore damage including trampling, scat, and browsing. The summit area sections are used to measure the exact dimensions of the peak (area and slope), the coarse-scale ground cover of the peaks (7 cover classes: solid rock, scree, vascular plants, lichens, bryophytes, bare ground, and litter), and the presence of individual plant species used to estimate species diversity and exotic plant cover (Table 2).

Table 2. Types of plots present on each GLORIA summit and data available for analyses. Each quadrat cluster contains 9 quadrats, but only 4 are sampled for vascular plants. One out of the four was sampled for lichen species.

\begin{tabular}{|l|l|c|l|l|}
\hline Plot type & Size & $\begin{array}{l}\text { Number of } \\
\text { plots per } \\
\text { peak }\end{array}$ & $\begin{array}{l}\text { Number of } \\
\text { plots in } \\
\text { YELL }\end{array}$ & Available Data \\
\hline Summit & $\begin{array}{l}\text { Variable from 0 to 10m } \\
\text { below highest point }\end{array}$ & 1 & 4 & Natural and anthropogenic disturbance \\
\hline $\begin{array}{l}\text { Summit } \\
\text { Area }\end{array}$ & $\begin{array}{l}\text { Variable from 0-5m and 5- } \\
\text { 10m below highest point } \\
\text { for each direction }\end{array}$ & 8 & 32 & $\begin{array}{l}\text { Species presence; } \\
\text { Cover class }\end{array}$ \\
\hline $\begin{array}{l}\text { Quadrat } \\
\text { cluster }\end{array}$ & $9 \mathrm{~m}^{2}$ & 4 & 16 & $\begin{array}{l}\text { Hourly soil temperature; } \\
\text { Soil parameters }\end{array}$ \\
\hline Quadrat & $1 \mathrm{~m}^{2}$ & 16 & 64 & $\begin{array}{l}\text { Cover class; } \\
\text { Species cover; } \\
\text { Species frequency; Frequency of herbivore damage }\end{array}$ \\
\hline
\end{tabular}

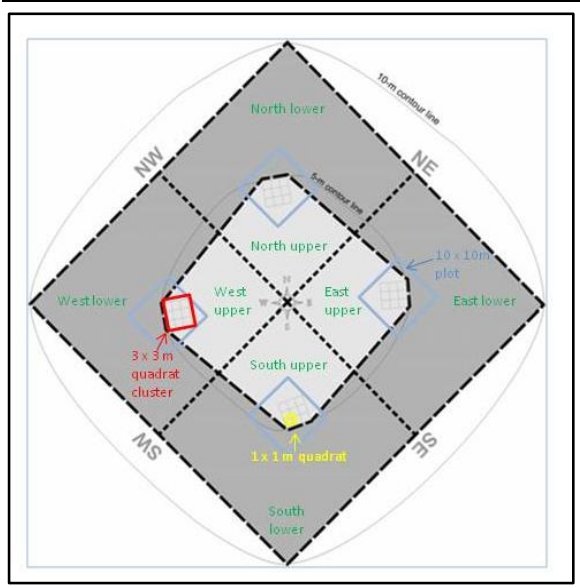

Figure 4. Example of the field plot design used for alpine monitoring, which was replicated on four summits varying in elevation. The design is centered by the highest point on the summit, and extends to $10 \mathrm{~m}$ in elevation below the highest point. The $1 \mathrm{~m}^{2}$ quadrats used to measure changes in vascular and non-vascular plant frequency are indicated in yellow. 


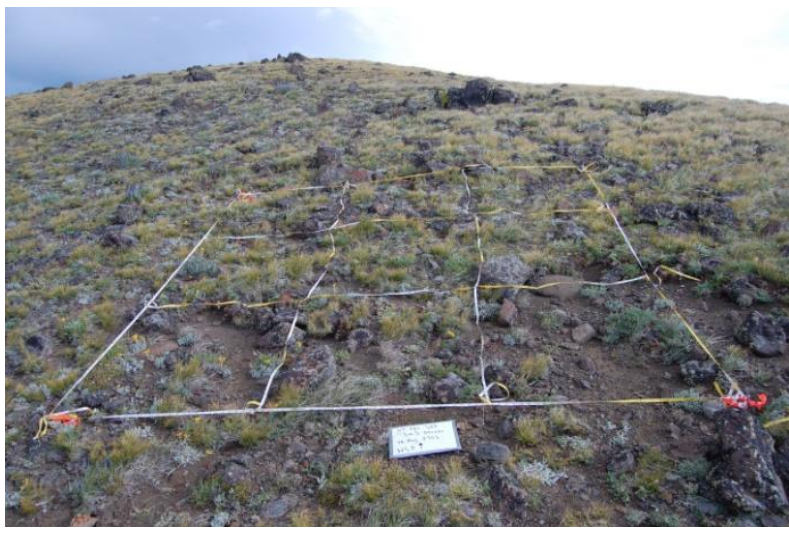

Figure 5. A divided meter tape outlines a $3 \times 3$ m quadrat cluster on the south side of one of the GLORIA peaks (SPP). Photograph by Monica Kopp.

After establishing and photographing the quadrats on all peaks, we installed 4 temperature loggers per peak buried $10 \mathrm{~cm}$ in the soil, measured plant cover and frequency in at least eight $1 \mathrm{~m}^{2}$ quadrats per peak, measured lichen cover and frequency in four $1 \mathrm{~m}^{2}$ quadrats per peak, and surveyed all summit area sections to determine changes in species diversity by elevation and aspect. We chose the lower left and upper right quadrats for sampling and priority will be given for sampling this subset in the future. Cover was measured in the quadrat by ocular estimate and frequency was measured as the presence of a species in one hundred $10 \times 10 \mathrm{~cm}$ grid cells with the quadrat. We installed HOBO Onset pendant temperature loggers (UA-00164) that are programmed to measure and record temperature every hour. To aid in identification, some plant specimens were collected, identified using regional floras, and compared to herbarium specimens. Lichen specimens were collected outside of the Summit Area Section, and care was taken to obtain specimens of all taxa found within all $1 \mathrm{~m}^{2}$ quadrats.

We also collected a bulk soil sample (an aggregate of 3 cores to $20 \mathrm{~cm}$ depth) from each of the quadrat clusters to characterize soil chemistry and texture. The soil samples were air dried and sent to a cooperating laboratory at Colorado State University for analysis. In order to qualitatively describe disturbance, we documented the presence of potential stressors in and around each site. Using applicable metrics from the 2008 Human Disturbance Index developed by the Colorado Natural Heritage Program, (Rocchio 2007) and the California Rapid Assessment Method for Wetlands (Collins et al. 2008) we indicated a condition score for each site that ranges from 0 (pristine) to 100 (highly disturbed).

In total, the field work for 2011 took 17 days, four of which were used for travel and access to and from backcountry campsites. As the peaks were all within a close distance of each other, all four peaks could be accessed from one campsite, cutting down on travel time. Initial set-up and establishment of the four peaks took five people roughly six days to complete. This included the datalogger installation and soil sampling for the four peaks. The remaining 7 days of field work were spent acquiring vegetation data, identifying plant species, photographing the summits and obtaining locational data, and sampling lichens and mosses. In the future, we expect the vascular and non-vascular plant sampling to occur more quickly because we now have established species lists for each summit, but we will also allow for more days of field work to compensate for bad weather and short work days.

\section{Lichen identification}

Lichen specimens were collected at each of the four peaks at the GLORIA site. Field identification was conducted where possible, and lichen species detected in $1 \mathrm{~m}^{2}$ quadrats were collected outside the sampling area for identification. All vouchers were taken to the University of Kansas Herbarium. Identifications were performed using a variety of techniques: chemical spot tests, Thin Layer Chromatography (TLC), and spore examination. TLC plates are deposited at the Colorado Natural Heritage Program. Lichen specimens are identified and labels have been produced. Vouchers will be stored at the University of Kansas, with a duplicate set provided to the Yellowstone Herbarium.

\section{$\downarrow \quad$ RESULTS}

We report on results of 40 numbered collections of lichens collected at four alpine sites in the Absaroka Range, Yellowstone National Park. A total of 21 unique taxa were documented. Of these, 6 are new to the documented lichen flora of Yellowstone (Eversman 1998, Eversman et al. 2002). Moss specimens are pending identification.

\section{Annotated Checklist}

The checklist is alphabetical by species name. Although most taxa were documented within monitoring plots at all sites, only the collection site for the voucher specimens are indicated here. 
Nomenclature follows Nash et al. 2001. The format and abbreviations associated with individual taxa in the checklist is as follows:

Taxon Authority (Collection numbers TLC number) Site Number(s); substrate or species ! indicates an addition to the Yellowstone lichen flora.

! Acarospora scabrida Hedl. ex H. Magn. (8054, 8078a, 8085, 8100); Sites 1, 2, 3, 4; rock

! Aspicilia americana B. de Lesd. (8072a); Site 1; rock

! Aspicilia desertorum (Kremp.) Mereschk. (8072b, 8080a, 8086, 8095); Sites 1, 3, 4; rock, soil

Caloplaca tiroliensis Zahlbr. (8091); Site 3; moss

Candelariella rosulans (Mull. Arg.) Zahlbr. (8077b, 8090, 8096); Sites 1, 3, 4, rock

! Cetraria islandica subsp. islandica (L.) Ach. (8093

TLC 1-11); Site 3; soil

Cetraria muricata (Ach.) Eckfeldt (8094 TLC 1-12);

Site 3; soil

! Cladonia acuminata (Vain.) Lynge (8087 TLC 114); Site 3; soil

Cladonia cariosa (Ach.) Spreng. (8081 TLC 1-15);

Site 1; soil

Lecanora garovaglii (Körb.) Zahlbr. (8088 TLC 1-5);

Site 3; rock

Lecanora polytropa (Hoffm.) Rabenh. (8055); Site 2; rock

Lecidea atrobrunnea (Ramond ex Lam. \& DC.) Schaer. (8097); Site 4; rock

Lecidella stigmatea (Ach.) Hertel \& Leuckert (8076

TLC 1-6, 8084); Site 3; rock

Peltigera canina (L.) Willd. (8092); Site 3; moss, soil, Selaginella densa

Physconia muscigena (Ach.) Poelt (8083a); Site 1; soil, Selaginella densa

Rhizoplaca melanopthalma (DC.) Leuckert \& Poelt (8070 TLC 1-9, 8072c, 8073 TLC 1-7, 8077a, 8080b, 8082 TLC 1-3); Site 1, rock

! Rinodina roscida (Sommerf.) Arnold (8083b); Site 1; soil

Staurothele areolata (Ach.) Lettau (8089, 8098); Site 3,4 ; rock

Thamnolia subuliformis (Ehrh.) W.L. Culb. (8056 TLC 1-8); Site 2; soil

Umbilicaria virginis Schaer. (8071a, 8072d, 8078c); Site 1 ; rock

Xanthoria elegans (Link) Th. Fr. (8069, 8078d, 8080c); Site 1; rock

\section{$\downarrow$ DISCUSSION}

Lichen species diversity was relatively low at the YELL GLORIA site (21), as compared to the
Rocky Mountain National Park site (ca. 90) (Egan 1971; Henson 2011 unpublished; Willard 1979). However, a large percentage (6 out of 21) of the species documented in our study are new to the lichen flora of Yellowstone. Overall diversity at the GLORIA site is possibly due to the volcanic (andesite) substrates and poorly developed soils that are present at the YELL site. A thin layer of fine, loose scree covers the bedrock at many of the northfacing aspects of the peak. Snowfields on the north and west aspects of the peaks linger late into the summer, and when melting move the scree downhill. Due to an inadequate amount of material, the following specimens were tentatively identified: Candelariella sp. (8071b), Lecidella aff. stigmatea (8071c), Lecidella aff. patavina (8099). Two species, Placidium squamulosum and Sporastatia testudina, were identified within the plot, but adequate material was not available to collect voucher specimens. Although moss cover was very low at the GLORIA site, all moss specimens will be mailed to Judy Harpel for identification. The GLORIA Network is processing all 2011 field data, and will be returning the completed database to ROMN and CNHP in the spring/summer of 2012.

\section{$\uparrow$ ACKNOWLEDGEMENTS}

This project was made possible by the funding from the University of Wyoming-National Park Research Station and the National Park Service Rocky Mountain Inventory and Monitoring Network (ROMN). Special thanks to Hank Harlow and Celeste Havener from UW-NPS for making this project possible. Mike Britten and Isabel Ashton from ROMN for their assistance with the GLORIA project. Ann Henson provided field assistance in lichen identification. Caleb Morse graciously donated his time and expertise to assist with the identification of lichen specimens. Erin Shanahan, Kristen Long, Laura O'Gan, Jennifer Whipple, and Christie Hendrix all provided assistance with the GLORIA project logistics. Special thanks to Meade and Andrea Dominick and the staff of the 7D Ranch for packing field and crew supplies into our remote camp site, and to the members of the Yellowstone National Park Dispatch. CNHP would also like to thank Andrew Pills and Julie Lyon with the Shoshone National Forest for input regarding logistics and for the use of the Sunlight Ranger Cabin as a crew base. Lastly, Lighthawk pilots Richard Spencer and Lisa Robertson kindly donated flights to help our crew evaluate terrain and approach. 


\section{$\downarrow$ LITERATURE CITED}

Ashton I, Britten M, Shorrock D, and Schweiger B. 2010. Alpine vegetation composition, structure, and soils monitoring for Rocky Mountain National Park: 2009 Summary Report. Natural Resource Program Center. Fort Collins, Colorado. Natural Resource Data Series. NPS/ROMN/NRDS-2010/057.

Collins JN, Stein ED, Sutula M, Clark R, Fetscher $\mathrm{AE}$, Grenier L, Grosso C, and Wiskind A. 2008. California Rapid Assessment Method (CRAM) for Wetlands, v. 5.0.2. http://www.cramwetlands.org /documents/

Eckel PM. 2007. County checklist of the Mosses of Wyoming. Res Botanica, a Missouri Botanical Garden Web Site. http://www.mobot.org/plantscience/resbot/1 Bryo.htm. Version Date August 17, 2007.

Egan R. 1971. A Floristic Study of Alpine Lichens from Colorado and New Mexico. PhD Dissertation. University of Colorado, Boulder, CO.

Eversman S. 1990. Lichens of Yellowstone National Park. The Bryologist. 93(2):197-205.

Eversman S. 1998. Lichens of Grand Teton National Park, Wyoming, pp. 295-308. In: Glenn MG, Harris RC, Dirig R and Cole MS (eds.), Lichenographia Thomsonii: North American Lichenology. Mycologia, Ltd., Ithaca, NY.

Eversman S, Wetmore CM, Glew K, Bennett JP. 2002. Patterns of lichen diversity in Yellowstone National Park. The Bryologist 105:27-42.

Flora of North America Editorial Committee. Editors, Flora of North America North of Mexico. Vol. 27 (Bryophyta, part 1): 539-561. New York: Oxford University Press. 2007.

Grabherr G, Gottfried M, Paull H. 2001. GLORIA: A Global Observation Research Initiative in Alpine environments. Mountain Research and Development 20:190-191.
Harpel J. 2011. Personal Communication with B. Kuhn regarding interest in identifying moss collections from GRTE and YELL. Email on February 22, 2011.

Henson A. 2011. Checklist of the lichens in the Alpine, Rocky Mountain National Park. Unpublished.

McCune B, Goward T. 1995. Macrolichens of the Northern Rocky Mountains. Mad River Press, Arcata, California. 208 pp.

Nash TH III, Ryan BD, Gries C, Bungartz F, editors. Lichen flora of the great Sonoran desert region Vol1 Tempe AZ: Lichens Unlimited. 2002

Pauli H, Gottfried M, Hohenwallner D, Reiter K, Casale R, Grabherr G, editors. 2010. The GLORIA Field Manual-Multi-Summit Approach. The Global Observation Research Initiative in Alpine EnvironmentsA contribution to the Global Terrestrial Observing System (GTOS). By the Office for Official Publications of the European Communities, Luxembourg, Belgium. Downloaded from www.gloria.ac.at on May 25, 2010.

Rocchio J. 2007. Floristic quality assessment indices for Colorado plant communities. Unpublished report prepared for the Colorado Department of Natural Resources and US EPA Region 8. Colorado Natural Heritage Program, Colorado State University, Fort Collins.

Spence JR. 1985. Checklist of the Mosses of Grand Teton National Park and Teton County, Wyoming. Great Basin Naturalist. 45: 124126.

Willard B. 1979. Plant Sociology of the Alpine Tundra, Trail Ridge, Rocky Mountain National Park. In Quarterly of the Colorado School of Mines 74: 4. 